NBER WORKING PAPER SERIES

\title{
CREATIVE DESTRUCTION AND DEVELOPMENT: INSTITUTIONS, CRISES, AND RESTRUCTURING
}

\author{
Ricardo J. Caballero \\ Mohamad L. Hammour \\ Working Paper 7849 \\ http://www.nber.org/papers/w7849
NATIONAL BUREAU OF ECONOMIC RESEARCH 1050 Massachusetts Avenue
Cambridge, MA 02138
August 2000

Prepared for the Annual World Bank Conference on Development Economics, Washington, D.C., April 1820, 2000. We thank Abhijit Banerjee for his discussion of our paper and two anonymous referees for their suggestions. The views expressed herein are those of the authors and not necessarily those of the National Bureau of Economic Research.

(C) 2000 by Ricardo J. Caballero and Mohamad L. Hammour. All rights reserved. Short sections of text, not to exceed two paragraphs, may be quoted without explicit permission provided that full credit, including (C) notice, is given to the source. 
Creative Destruction and Development: Institutions, Crises, and Restructuring

Ricardo J. Caballero and Mohamad L. Hammour

NBER Working Paper No. 7849

August 2000

JEL No. E0, J3, O1, O3, O4

\begin{abstract}
There is increasing empirical evidence that creative destruction, driven by experimentation and the adoption of new products and processes when investment is sunk, is a core mechanism of development. Obstacles to this process are likely to be obstacles to the progress in standards of living. Generically, underdeveloped and politicized institutions are a major impediment to a well-functioning creative destruction process, and result in sluggish creation, technological "sclerosis," and spurious reallocation. Those ills reflect the macroeconomic consequences of contracting failures in the presence of sunk investments. Recurrent crises are another major obstacle to creative destruction. The common inference that increased liquidations during crises result in increased restructuring is unwarranted. Indications are, to the contrary, that crises freeze the restructuring process and that this is associated with the tight financial-market conditions that follow. This productivity cost of recessions adds to the traditional costs of resource under-utilization.
\end{abstract}

Ricardo J. Caballero

Department of Economics

MIT

50 Memorial Drive, E52-252A

Cambridge, MA 02142

and NBER

caball@mit.edu
Mohamad L. Hammour

DELTA - ENS

48 boulevard Jourdan

75014 Paris

FRANCE 


\section{Introduction}

The world economy today is undergoing momentous reorganization in the face of the development and large-scale adoption of information technologies. Alan Greenspan 1999 describes the recent US experience in the following words: "The American economy, clearly more than most, is in the grip of what ... Joseph Schumpeter ... called 'creative destruction,' the continuous process by which emerging technologies push out the old. ... The remarkable ... coming together of the technologies that make up what we label IT information technologies - has begun to alter, fundamentally, the manner in which we do business and create economic value". This wave of restructuring is only the latest manifestation of creative destruction, by which the production structure weeds out unproductive segments; upgrades its technology, processes, and output mix; and adjusts to the evolving regulatory and global environment.

Ongoing restructuring is as relevant for the developing world as it is for economies at the leading edge of technology. In this paper, we draw on the significant advances over the past decade in theoretical and empirical research on creative destruction to formulate a number of propositions concerning the role and workings of this mechanism in the development process. Some of the ideas we put forward are firmly grounded in empirical evidence; others are not more than hypotheses consistent with a combination of theoretical considerations and scattered evidence, but which deserve systematic investigation in the future.

The rest of this paper is organized into three sections. In the first section, we review recent international evidence on gross job flows that supports the idea that creative destruction is a core mechanism of growth in market economies. Our discussion revolves around three basic facts. First, the large, ongoing, and persistent gross job creation and destruction flows exhibited by all market economies studied provides evidence of extensive ongoing restructuring activity. Second, this reallocation process shifts resources over time from low to high-productivity sites, and is found to account for a large share of the growth in productivity. This highlights the central role of creative destruction in 
productivity growth. Third, the very large majority of gross flows take place within narrowly defined sectors of the economy. This implies that traditional analyses of restructuring that emphasize shifts across production sectors and associated relative price changes only capture a small component of this phenomenon. The bulk of what we observe calls for a different sort of analysis, which emphasizes theories of experimentation and technology adoption (Levinsohn 1999 and Melitz 1999 apply those ideas to trade reform, Olley and Pakes 1996 to industrial deregulation, and Caballero and Hammour 1999 to the effect of crises on restructuring activity). Further exploration of the role played by those silent flows may call for a shift in the development paradigm from the idea of a "big push" to a myriad of "little nudges."

If creative destruction is a core mechanism of economic growth, obstacles to this process are likely to be obstacles to development. This is of particular relevance to many developing economies today, which have opened up their markets and must now face the challenge of not only catching up, but keeping up with world standards. The second section argues that institutional impediments are likely to constitute major obstacles to a well-functioning creative destruction process, and explores their consequences. Any notion of restructuring is built on the assumption that investment in capital and skills is partly irreversible, and specific with respect to technology or the other factors of production it combines with. Relationship specificity requires inter-temporal contracting, for which a proper institutional framework is critical. If we consider institutional failure as the root obstacle to growth in the developing world, it is likely to constitute a major impediment to creative destruction.

We explore the consequences of constrained contracting ability in the financial and labor markets on the restructuring process. Generically, such problems result in depressed creation; technological sclerosis, in the form of inefficient survival of low-productivity units; a disruption of the strict productivity ranking based on which efficient entry and exit should take place; and privately inefficient separations. Such ills can be as much a result of underdeveloped institutions as one of politicized institutions in response to the distributional effects of restructuring. On the empirical front, we explore available 
evidence on job flows in LDCs and the many issues that arise in bringing the data to bear on the above questions. Although there is evidence of significant job flows in some LDCs, those flows may reflect a highly unproductive restructuring process. However, to reach any conclusive evidence, a much more structural empirical approach is required than what has been attempted so far.

The third section argues that recurrent crises in the developing world are likely to constitute a second major obstacle to creative destruction. This line of argument contradicts the commonly held view that observed sharp liquidations during crises result in increased restructuring. However, jobs that are destroyed during a recession mostly feed into formal unemployment or under-employment in the informal sector, and not directly into newly created jobs. We argue that this issue can only be examined dynamically, and depends crucially on the behavior of creation and destruction during the ensuing recovery. We extrapolate from empirical work on US gross flows the proposition that, on the contrary, crises freeze the restructuring process and that this phenomenon is due to the tight financial conditions following a crisis, which reduce the ability to finance the creation of new production units. Given the presumption that developing economies suffer from technological sclerosis, the result is a productivity-cost of crises that adds to the traditional costs associated with under-utilized resources.

\section{Creative Destruction and Economic Growth}

In this section, we review recent empirical evidence that supports the notion that the process of creative destruction is a major phenomenon at the core of economic growth in market economies - an idea that goes back to Joseph Schumpeter 1942, who considered it "the essential fact about capitalism" (p. 83).

Underlying any notion of restructuring is the assumption that choices of technology, output mix, modes of organization are embodied in capital and skills. This irreversibility of investment entails that adjusting the production structure requires that existing 
investments be scrapped and replaced by new ones. If, on the contrary, capital were perfectly malleable and skills fully generic, adjustment would be costless and instantaneous. At a conceptual level, it is the embodiment of technology combined with incessant opportunities to upgrade the production structure that place ongoing restructuring at the core of the growth process, irrespective of whether the economy is a technological leader or laggard.

Restructuring is closely related to factor reallocation. If investments need to be scrapped, it is because they are working with factors of production that must be freed up to combine with new forms of investment. In other words, restructuring generates a reallocation of factors in which technology is not embodied. This link has been exploited empirically to develop measures of reallocation that can be used as an index of restructuring. The most successful measures developed so far are based on labor reallocation, although there have been attempts to look at other factors (see, e.g., Ramey and Shapiro 1998). ${ }^{3}$

The literature on gross job flows has constructed measures of aggregate gross job creation and destruction based on microeconomic data at the level of business units - i.e., plants or firms (see Davis and Haltiwanger 1998 for an excellent survey). Gross job creation over a given period is defined as employment gains summed over all business units that expand or start up during the period; gross destruction corresponds to employment losses summed over all units that contract or shut down. Although job flows constitute a useful indicator of restructuring, the link between the two is loose. It is quite possible that plant equipment and organization be entirely upgraded in a given location without a change in the number of jobs; conversely, it is possible that jobs may migrate from one location to another (e.g., for tax reasons) to perform exactly the same activity.

Many studies are now available that construct measures of job flows for different countries. Three features of the data have emerged that allow us to characterize the role of creative destruction in the growth process: 
1. Gross job creation and destruction flows are large, ongoing, and persistent.

2. Most job flows take place within rather than between narrowly defined sectors of the economy.

3. Job reallocation from less-productive to more-productive business units plays a major role in industry-level productivity growth.

Starting with the first feature, table 1 summarizes the average annual job flows measured for different economies. Job flows are generally large, both in high-income countries and for the few observations we have of LDCs (Colombia, Chile and Morocco) and transition economies (Estonia). It is very common that an average of at least one in ten jobs turns over in a year. Creation and destruction flows are simultaneous and ongoing. In US manufacturing over the period 1973-88, for example, the lowest rate of job destruction in any year was 6.1 percent in the 1973 expansion; and the lowest rate of creation was 6.2 percent in the 1975 recession. ${ }^{4}$ Moreover, the bulk of those flows are not a case of temporary layoffs - which would not correspond to true restructuring. Table 2 presents data for a number of countries on the high persistence rates of job creation and destruction over a one-year and a two-year period (i.e., the percentage of newly created jobs that remain filled over the period; or of newly destroyed jobs that do not reappear over the period). Overall, job flow data seem to indicate extensive ongoing restructuring activity.

The second feature of the data is that reallocation across traditionally defined sectors accounts for only a small component of job flows. To measure the amount of creation and destruction that take place simultaneously above the amount required to accommodate net employment changes, define excess job reallocation as the sum of job creation and destruction minus the absolute value of net employment change. Table 3 presents data for various economies on the fraction of excess reallocation accounted for by employment

\footnotetext{
${ }^{3}$ An alternative empirical approach to creative destruction focuses on physical capital, and asks how much of output growth is associated with capital-embodied technological progress. See Hulten 1992 and Greenwood, Herkowitz and Krusell 1997.

${ }^{4}$ See Davis, Haltiwanger and Schuh 1996, table 2.1, p. 19.
} 
shifts between narrowly defined sectors. This fraction never exceeds one-fifth, and is typically well below this level.

There seems to be two major factors behind within-sector reallocation: adjustment and experimentation. Needless to say, several job characteristics that are important determinants of employment adjustment are not captured by output-based sectoral classifications. The job may be associated with capital or skills of an outdated vintage (see, e.g., Caballero and Hammour 1996b), or may have suffered a highly idiosyncratic disruption. In addition, it appears that a large component of job flows is due to experimentation in the face of uncertain market prospects, technologies, cost structures, or managerial ability (see, e.g., Jovanovic 1982). This idea is supported by evidence from US manufacturing and elsewhere that younger plants exhibit higher excess reallocation rates, even after controlling for a variety of plant characteristics (see Davis and Haltiwanger 1998, p. 18 and figure 4.2).

Traditional analyses of restructuring in the trade and development literature emphasize one dimension of the creative destruction process - namely major shifts between main sectors of the economy. Much less noticed is the multitude of creation and destruction decisions driven by highly decentralized idiosyncratic factors and experimentation, whose role is potentially equally important. Many conventional questions in development may come under a new light once we consider the role played by those underlying flows. For example, Levinsohn 1999 and Melitz 1999 argue that a significant benefit of trade reform arises through this channel from factor reallocation toward more productive firms. In a similar vein, Olley and Pakes 1996 find that deregulation in the U.S. telecommunications industry increased productivity predominantly through factor reallocation toward more productive plants, rather than through intra-plant productivity gains. Our coming discussion of the effect of crises on restructuring activity and its costs in terms of productivity constitutes another example.

The function of large within-sector job flows and their relation to productivity gains brings us to the third feature of the data. There is evidence that factor reallocation is a 
core mechanism in the growth of productivity. Foster, Haltiwanger and Krian 1998 conduct a careful study and survey of this question. Examining four-digit U.S. manufacturing industries over the ten years 1977-1987, they decompose industry-level multifactor productivity gains over the period into a within-plant term and a reallocation term. The within-plant term reflects productivity gains within continuing plants weighted by their initial output shares; the reallocation term reflects productivity gains associated with reallocation between continuing plants, entry and exit. They find that reallocation accounts on average for 52 percent of ten-year productivity gains. Entry and exit account for half of this contribution: plants that exit during the period have lower productivity than continuing plants; plants that enter only catch up gradually with continuing plants, through learning and selection effects.

Other studies of US manufacturing based on somewhat different methodologies (see Baily, Hulten and Campbell 1992; Bartelsman and Dhrymes 1994) concur with the conclusion that reallocation accounts for a major component of within-industry productivity growth. It would be of great interest to know whether restructuring is as productive in LDCs as it is in the US, but relevant studies are few and give rise to methodological issues. Aw, Chen and Roberts 1997, focus on Taiwan; Liu and Tybout 1996 on Colombia. Both define the within-plant term of their productivity decomposition based on a plant's average share over the period rather than its initial share. ${ }^{5}$ As discussed by Foster et al. 1998, this tends to under-estimate the contribution of reallocation across continuing plants. Moreover, both studies conduct their decomposition over a horizon shorter than ten years: five years for Taiwan, and only one year for Colombia. This reduces the contribution of entry, which takes place dynamically through the above-mentioned learning and selection effects. It is also more sensitive to the cyclicality of productivity, which one expects to affect productivity growth mostly within plants. The resulting contribution of reallocation to average productivity gains is 34 percent for Taiwan, and near zero for Colombia. ${ }^{6}$ Given the methodological

\footnotetext{
${ }^{5}$ In fact Aw, Chen and Roberts 1997 use firm rather than plant-level data, and define a within-firm term.

${ }^{6}$ Since sector weights are not provided by Aw et al. 1997, the calculated average contribution gives equal weight to the TFP growth rates in their table 12.
} 
differences, it is difficult to know whether this implies that factor reallocation in those LDC countries is less productive than in the US.

The evidence of extensive, ongoing job flows that are pervasive throughout the economy and constitute a major mechanism of productivity growth points to the centrality of creative destruction in the growth process. Whether ongoing restructuring is, in fact, as productive in LDCs as it is in an advanced economy like the US is a major concern, but it does not diminish the potential importance of this process for growth. A corollary is that obstacles to creative destruction are likely to be obstacles to development, and should be of central concern to development theory and policy. Such potential obstacles are the focus of the rest of this paper.

\section{Institutions and Restructuring}

We have seen that the notion of restructuring presumes that investment is partly irreversible. When two factors of production enter into a production relationship, they develop a degree of specificity with respect to each other and to the choice of technology, in the sense that their value within this arrangement is greater than their value outside. In the presence of specificity, the institutional environment becomes critical. The reason is, very generally, that irreversibility in the decision to enter a production relationship with another factor creates ex-post quasi-rents that need to be protected through ex-ante contracting (Klein, Crawford and Alchian 1978). If contracting ability is limited, it is the institutional environment that determines the rules by which those quasi-rents are divided. Poor institutions, by definition, prevent one of the parties to a transaction from getting the value of what it put in. This disrupts the broad range of financing, employment and output sale transactions that underlie a healthy creative destruction process. 
We view institutional failure as the root obstacle to economic growth in the developing world. ${ }^{7}$ This leads us to the presumption that poor institutions are likely to constitute a major disruption to creative destruction. To the extent that investment irreversibility takes on an entirely new dimension in the presence of contracting difficulties, it becomes of crucial import for the analysis of development.

In this section, we propose a simple model of the distortions that are likely to affect the restructuring process and examine related empirical evidence. Our treatment of institutions is deliberately very generic. Our purpose is not to comment about specific arrangements, but to identify a common element likely to affect creative destruction in a systematic fashion and which is shared by many examples of institutional failure financial markets that lack transparency and investor protection, overly protective labor regulations, highly politicized and uncertain competitive regulations, etc.

\section{Theoretical Considerations}

A basic model. We develop a basic model, based on Caballero and Hammour 1998a, which focuses on specificity in the financing and employment relationships and its implications for aggregate restructuring. For this purpose we introduce three factors of production: capital, entrepreneurs, and labor. The specificity of capital with respect to entrepreneurs affects financing transactions; its specificity with respect to labor affects employment transactions. All three factors exist in infinitesimally small units. Entrepreneurs and labor have linear utility in the economy's unique consumption good, which we use as numéraire.

Contracting obstacles affect the possibility of economic cooperation. In order to capture their implications at a general level, we define for each factor two possible modes of production: Autarky and Joint Production (see figure 1). In Joint Production, the three factors combine in fixed proportions to form production units. Each such unit is made up

\footnotetext{
${ }^{7}$ See Lin and Nugent 1995 for a broad review.
} 
of (i) a unit of capital; (ii) an entrepreneur $i$; and (iii) a worker. Each entrepreneur $i$ has an innate level of skill that determines the production unit's productivity, measured by the amount $y_{i}$ of the consumption good the unit can produce. Each entrepreneur also starts with a level of net worth $a_{i} \geq 0$ that can finance part of the unit's capital requirement. The remaining financing requirement, $b_{i}=1-a_{i}$ is provided by external financiers. We assume that workers start with zero net worth. Cooperation in Joint Production gives rise to investment specificity: once committed, capital is fully specific to the entrepreneur and the worker. It has no ex-post use outside its relationship with them.

The Autarky mode of production is free from investment specificity. If they do not participate in a Joint Production unit, factors can operate in the following Autarky modes: (i) Capital can be invested in the international financial markets at a fixed world interest rate $r^{A}>0$ (" $A$ " stands for Autarky). (ii) If an entrepreneur does not enter Joint Production, he simply also invests his net worth at the world interest rate. (iii) Autarky for Labor corresponds to employment in the "informal" sector at a wage $w^{A}$ given by the informal-sector labor demand function:

$$
U=U\left(w^{A}\right), \quad U^{\prime}<0,
$$

where $U$ stands for informal-sector employment.

In order to analyze restructuring, we assume the economy starts with pre-existing production units as well as a supply of uncommitted factors of production. Events take place in three consecutive phases: destruction, creation, and production. In the destruction phase, the factors in all pre-existing units decide whether to continue to produce jointly, or to separate and join the uncommitted factors. In the creation phase, uncommitted factors either form new Joint Production units or remain in Aurarchy. In the final phase, production takes place and factor rewards are distributed and consumed. If the factors in a Joint Production unit separate after the creation phase, their only option is to move back to Autarky. 
Introducing pre-existing units allows us to analyze destruction decisions. We assume their productivity distribution is over the interval $y^{o} \in\left[0, y^{\max }\right]$ and, for simplicity, that it has negligible mass. The supply of uncommitted factors is as follows. (i) The supply of capital is unlimited. (ii) The supply of entrepreneurs with any given productivity $y \in[0$, $\left.y^{m a x}\right]$ is also unlimited, but not all of them have positive net worth. We assume that entrepreneurs with positive net worth are distributed according to a uniform density $\phi>0$ for each productivity level, and that they all have sufficient funds to fully finance a production unit $\left(a_{i}>1\right)$. (iii) The aggregate mass of labor is one, so that employment in Joint Production is given by

$$
L=1-U\left(w^{A}\right) .
$$

Efficient equilibrium. We first derive the economy's efficient-equilibrium conditions, which would arise if agents had perfect contracting ability. We restrict ourselves to parameter configurations that result in an interior equilibrium $(0<L<1)$. On the creation side, given that the supply of entrepreneurs with the highest productivity $y^{\max }$ is unlimited and that the Autarky return on capital is $r^{A}$, labor's Autarky wage must satisfy

$$
w^{A^{*}}=y^{\max }-r^{A}
$$

(a “*” denotes efficient equilibrium values). Any wage below this value would induce infinite Joint Production labor demand; and any wage below would induce zero demand. The labor demand and supply system (2)-(3) determines the efficient equilibrium creation of Joint Production units, as illustrated in figure 2. Note that the Joint Production rewards for capital and labor are equal to their Autarky rewards, and that the reward for entrepreneurs is zero because of their unlimited supply.

On the destruction side, scrapping the capital invested in a pre-existing unit frees up a unit of labor. Efficient exit will therefore affect all units with productivity levels 


$$
y^{o}<w^{A^{*}}
$$

Incomplete-contracts equilibrium. Because of investment specificity, implementing the efficient equilibrium requires a contract that guarantees capital in Joint Production its exante opportunity cost $r^{A}$. The contracting incompleteness we introduce is due to the inalienability of human capital, which renders unenforceable any contracting clause that removes the right of the entrepreneur or the worker to walk away from the Joint Production relationship ex post (see Hart and Moore 1994). This affects both the employment transaction between labor and capital, and the financing transaction between the entrepreneur and external financiers.

Starting with the employment relationship, we assume that the worker deals with the entrepreneur and his financier as a single entity. ${ }^{8}$ If production unit $i$ has productivity $y_{i}$, its associated specific quasi-rent $s_{i}$ is the difference between the unit's output and its factors' ex-post opportunity costs:

$$
s_{i}=y_{i}-w^{A}
$$

considering that the worker moves to Autarky if he leaves the production unit. Following the Nash bargaining solution for sharing the unit's output, we assume each party gets its ex-post opportunity cost plus a share of the surplus $s_{i}$. If $\beta \in(0,1)$ denotes labor's share:

$$
w_{i}=w^{A}+\beta s_{i} \quad \text { and } \quad \pi_{i}=(1-\beta) s_{i},
$$

where $w_{i}$ and $\pi_{i}$ denote the rewards of labor and capital, respectively. The contracting problem adds a rent component $\beta s_{i}$ to wages.

Turning to the financing relationship, the associated specific quasi-rents correspond to the full profit $\pi_{i}$ because the ex-post outside options of the entrepreneur and external 
financiers are worthless. Again, because of the inalienability of human capital, no contract can prevent the entrepreneur from threatening to leave the relationship. Any contract can be renegotiated according to the Nash bargaining solution, which gives the entrepreneur a share $\alpha \in(0,1)$ of $\pi_{i}$ and gives the external financier a share (1- $\left.\alpha\right)$. The firm's outside liability can therefore never exceed

$$
r^{A} b_{i} \leq(1-\alpha) \pi_{i}
$$

This financial constraint places a lower bound on the net worth $a_{i}=1-b_{i}$ the entrepreneur needs to start a project, which can be written as

$$
a_{i} \geq 1-(1-\alpha)(1-\beta)\left(y_{i}-w^{A}\right) / r^{A} .
$$

based on (5)-(6). We assume $\alpha$ is large enough that (8) requires positive net worth when $y_{i}=y^{\max }$. This implies that only entrepreneurs with positive net worth can enter Joint Production, in which case we have assumed that they have enough funds to fully finance a production unit.

We now solve for the incomplete-contracts equilibrium conditions. Starting with creation, an entrepreneur who is able to finance a production unit will find it profitable to do so if

$$
\pi_{i} \geq r^{A}
$$

which, given (5) and (6), is equivalent to

$$
y_{i} \geq w^{A}+[1+\beta /(1-\beta)] r^{A} .
$$

Because of the rent component in wages, capital behaves as if it faced a world interest rate higher than $r^{A}$. The Joint Production demand for labor is given by the mass of entrepreneurs whose productivity satisfies (10) and can finance a production unit:

\footnotetext{
${ }^{8}$ One reason could be that the entrepreneur can disguise proper funds as being external, and vice versa.
} 


$$
L=\phi\left[y^{\max }-w^{A}-[1+\beta /(1-\beta)] r^{A}\right] .
$$

Together with equation (2) for the supply of labor, this determines the incompletecontracts equilibrium level of $L$. As illustrated in figure 2, labor demand (11) under incomplete contracts falls below its efficient-economy counterpart (3). This occurs both because of labor-market rents (which shifts the curve down vertically) and because of the financial constraint (which rotates the curve down around its vertical-axis intercept). In the incomplete-contracts equilibrium, Joint Production employment and Autarky wages are lower than their efficient-equilibrium counterparts:

$$
L<L^{*} \quad \text { and } \quad w^{A}<w^{A^{*}} .
$$

Turning to destruction, note that a worker who leaves a pre-existing production unit will find employment in Joint Production with probability $L$, in which case we denote his expected wage by $E[w]$; and will remain in Autarky with probability $(1-L)$, in which case his wage will be $w^{A}$. The exit condition is therefore ${ }^{9}$

$$
y^{o}<L E[w]+(1-L) w^{A} .
$$

Characterization of equilibrium. We now characterize the general-equilibrium consequences of incomplete contracting. The imbalances we describe constitute a highly inefficient macroeconomic solution to the unresolved microeconomic contracting problems. We first discuss features of equilibrium that are highly suggestive of the experience of developing countries, but pertain only indirectly to restructuring; we then turn to direct implications for the restructuring process.

\footnotetext{
${ }^{9}$ In order to avoid issues related to the possibility that the entrepreneur may want to restart in a new production unit, we assume entrepreneurs in pre-existing units have zero net worth.
} 
1. Reduced cooperation. At the purely microeconomic level, it is well known that limited contracting ability hampers cooperation. We have seen that positive-value Joint Production projects may not be undertaken because labor (eqn. 6) or the entrepreneur (eqn. 7) can capture rents beyond their ex-ante opportunity costs.

2. Under-employment. As we have seen in the discussion of equation (12), Joint Production is characterized by under-employment $\left(L<L^{*}\right)$, which is an equilibrium consequence of obstacles to cooperation in the financial and labor markets. In partial equilibrium, rent appropriation reduces the Joint Production return on capital. In order to restore this return to the level $r^{A}$ required by world markets, fewer Joint Production units are created, informal-sector employment balloons, and the opportunity-cost component $w^{A}$ of wages falls (eqn. 6). Generally, the extent of under-employment depends on the supply elasticity of the factor that suffers from specificity, which we assume here to be infinite.

The counterpart of under-employment in Joint Production is an overcrowded informal sector $\left(U>U^{*}\right)$. The reason this happens is that we have assumed no need for contracting in Autarky. We view the informal sector as one where transactional problems are less severe because there is less need for cooperation with capital (due to low capital intensity or constant returns), because employment regulations can be evaded, etc. $^{10}$

3. Market segmentation. In the incomplete-contracts equilibrium, both the labor and financial markets are segmented. There are workers and entrepreneurs in Autarky who would strictly prefer to move into Joint Production, but are constrained from doing so. Put another way, those two factors earn rents in Joint Production. It is easy to see that the rent component of Joint Production wages in (6) is positive, and sets them strictly above the informal-sector wage. ${ }^{11}$ However, the presence of rents does not entail high wages, but quite the contrary. One can show that Joint Production

\footnotetext{
${ }^{10}$ Banerjee and Newman 1998 apply a similar interpretation to the traditional sector, which they see as a sector where contracting is easier because information asymmetries are less severe.
} 
wages are lower under incomplete contracts than in the efficient economy. To see this for any production unit $i$, replace $\pi_{i}=y_{i}-w_{i}$ into (9) to get

$$
w_{i} \leq y_{i}-r^{A} \leq y^{\max }-r^{A}=w^{A^{*}} .
$$

The rent component of wages arises through depressed wages in the informal sector, not because of high wages in Joint Production. Similarly, from (10), it is clear than an entrepreneur with intra-marginal productivity $y_{i}$ earns positive rents equal to $y_{i}-w^{A}$ $[1+\beta /(1-\beta)] r^{A}$ associated with the scarcity of internal funds. Those rents would not arise in an efficient equilibrium.

We now turn to the characteristics of equilibrium that pertain directly to restructuring. The first three properties characterize the amount of equilibrium creation and destruction of Joint Production units; the last two characterize the quality of restructuring, understood as the net gain that results from it.

4. Depressed creation. Since creation in this economy is equal to $L<L^{*}$, it follows that the equilibrium rate of creation is depressed compared to the efficient economy.

5. Sclerosis. The Joint Production structure suffers from sclerosis, in the sense that some production units survive that would be scrapped in an efficient economy. To see this, compare the efficient and incomplete-contracts exit conditions, (4) and (13). Since $w^{A}$ $<w^{A^{*}}$ was shown in (12) for Autarky and $w_{i} \leq w^{A^{*}}$ in (14) for Joint Production, it is clear that cost pressures to scrap are lower in the incomplete-contracts than in the efficient equilibrium. Sclerosis is thus a result of the under-utilization and low productivity of labor. Sluggish creation and sclerosis can impose a heavy drag on aggregate productivity.

6. Unbalanced restructuring. Destruction is excessively high compared to the depressed rate of creation. To see this, note that the private opportunity cost used in (13) for exit

\footnotetext{
${ }^{11}$ Simply note that (9) implies $\pi_{i}>0$.
} 
decisions is higher than the social shadow wage $w^{A}$ of labor. This is due to the possibility of capturing a rent component in wages, which distort upwards the private opportunity cost of labor. It may appear paradoxical that the economy exhibits both sclerosis and excessive destruction. In fact, the former is a comparison with the efficient equilibrium and the latter is a comparison between private and social values within the incomplete-contracts equilibrium. The unbalanced nature of gross flows is closely related to the presence of rents and market segmentation. In Caballero and Hammour 1996a, we argue that it sheds light on the nature of employment crises in developing countries.

7. Scrambling. In the efficient economy, only the most productive entrepreneurs with $y$ $=y^{\max }$ are involved in Joint Production. Had their number been insufficient, others would have been brought in according to a strict productivity ranking. On the creation side, an efficient process should result in the highest-productivity projects being implemented. This ranking is scrambled in the incomplete-contracts equilibrium, as another characteristic of the entrepreneur - net worth - comes into play. This tends to reduce the quality of the churn, in the sense that the same volume of scrapping and reinvestment will result in a smaller productivity gain.

8. Privately inefficient separations. A dimension that we have actually not incorporated in our model, but which can also constitute an important consequence of contracting difficulties, is the possibility of privately inefficient separations. This can come about through factors similar to those that make creation privately inefficient, in the sense that agents are constrained from starting positively valued projects. For example, assume that a production unit goes through a period of temporarily negative cash flow that must be financed if the unit is to remain in operation. Such continuation investment would help preserve the unit's specific capital, and is therefore itself specific and subject to a financial constraint. When the financial constraint is binding, destruction can be privately inefficient and result in losses for the owners of both labor and capital. ${ }^{12}$ This gives rise to another factor that reduces the quality of

\footnotetext{
${ }^{12}$ See, e.g., Caballero and Hammour 1999 for details.
} 
restructuring, as it generates spurious churn with little payoff in terms of productivity gains. Moreover, once we admit the possibility of private inefficiency on the destruction margin, then factors other than productivity may affect those decisions and also scramble the productivity ranking in exit decisions.

Political economy. Although contracting incompleteness was founded on the inalienability of human capital in our model, it can be due to a variety of factors. In particular, the legal and regulatory framework can, in itself, be a source of factor specificity and provide the institutional framework that determines the division of specific rents. Legal restrictions on employee dismissals, for example, would effectively make capital partly specific to labor in the Joint Production relationship analyzed above. Moving beyond an exogenous view of institutions, the final theoretical issue we touch on in this section concerns some of the underlying causes for the institutional obstacles to efficient restructuring.

Institutions play two distinct functions: efficiency and redistribution. On one hand, it is naïve to think that markets can generally function properly without an adequate institutional framework. In their efficiency role, we have seen that the basic principle that determines institutions is that each factor ought to get out the social value of what it put in - i.e., absent any externalities, its ex-ante terms of trade. On the other hand, it is equally naïve to think that such institutions, being partly determined in the political arena, will not also be used as an instrument in the politics of redistribution. A poor institutional framework is the result of a combination of under-development in the realm of contracting and regulations and of overly powerful political interest groups who have tilted the institutional balance excessively in their favor.

By displacing technologies and skills, creative destruction threatens a variety of incumbent interests, and can therefore itself give rise to political opposition and endogenous institutional barriers. Mere uncertainty concerning the impact of restructuring can, in fact, prop up opposition (Fernandez and Rodrick 1991). Mokyr 1992 
discusses many historical examples of resistance to technology adoption, perhaps the most popular of which is the nineteenth century Luddite movement in Britain (Thomis 1972). ${ }^{13}$ The response can range from mere neglect of the urgency of institutional reform to active barriers affecting trade, competition, regulation, the size of the government sector, as well as the financial and labor market dimensions that we focused on in our model.

As we have seen, a major pitfall of such protection, if intended to protect labor or other factors characterized by relatively inelastic supply, is that it can backfire and result in large-scale under-employment and internal segmentation between those who end up benefiting from protection and those who do not. This pitfall is worth highlighting as a number of Latin American economies (e.g., Chile and Argentina) go through the process of revising their labor codes in the context of ever increasing globalization and expanding outside options for capital (see Caballero and Hammour 1998b).

\section{A Look at Available Evidence}

Theoretically, we have argued that poor institutions generally result in a stagnant and unproductive creative destruction process. If one considers institutional failure as the fundamental illness of the developing world, then one would presume that sclerosis and a low-quality churn are prevalent phenomena.

Although this is consistent with low productivity in LDCs, one would like to find more direct evidence from job flows on this issue. At first sight, the data that were presented in table 1 do not seem to support the idea of sclerosis. Job flows in the few developing countries we have data on are of similar, if not larger, magnitude as in high-income

\footnotetext{
${ }^{13}$ Political economy considerations have not failed to arise in the current debate on the impact of the IT revolution: "a major consequence of rapid economic and technological change ... needs to be addressed: growing worker insecurity - the result, I suspect, of fear of potential job skill obsolescence. Despite the tightest labor markets in a generation, more workers report in a prominent survey that they are fearful of losing their jobs than similar surveys found in 1991 at the bottom of the last recession. ... Not
} 
countries (see Tybout 1998). However, there are several powerful reasons why this evidence cannot be taken at face value:

1. Measurement issues. First, it is important to keep in mind the lack of uniformity in job flow measures, which may undermine their comparability across countries. Table 1 highlights two major differences: sample coverage (manufacturing, private sector, all employees) and the basic employer unit (the plant or the firm). Other important differences are more difficult to trace, most notably the difficulties in linking observations longitudinally in the face of ownership or other changes. For example, Contini and Paceli 1995 report that attempts to correct Italian data for spurious births and deaths reduce job flows by about one-fifth. ${ }^{14}$

2. Industrial structure and employer characteristics. The magnitude of job flows varies systematically with industrial structure and employer characteristics. First, Davis and Haltiwanger 1998 show that the industry pattern of job reallocation intensity is quite similar across countries. A regression of reallocation on 2-digit industry fixed effects for pooled US, Canadian and Dutch data yields an R-squared of 48 percent (table 3.4). Although we are not aware of a systematic investigation of this issue, we would expect to find that LDC employment is heavily biased toward light industries with relatively low levels of investment specificity and that typically experience a fast turnover rate. One expects this type of restructuring with small re-investment requirements to yield commensurately low productivity gains. Moreover, rather than a sign of their ability to restructure, this may even be an indication that LDCs avoid industries where restructuring is expensive.

Second, Davis and Haltiwanger (1998, figure 4.1) summarize international evidence from seven countries for which job reallocation rates fall significantly with employer size. Compared to high-income countries, the bias in the size distribution in developing countries toward small plants is dramatic (see, e.g., Tybout 1998, table 1).

unexpectedly, greater worker insecurities are creating political pressures to reduce the fierce global competition that has emerged in the wake of our 1990s technology boom." (Greenspan 1999) 
This, by itself, predicts much larger job flows. How productive this type of reallocation is requires close interpretation. If small plant size is closely related to the light-industry bias with little technological lock-in, the benefits of restructuring may be small. Moreover, if small plant size is associated with greater financial fragility, some of the observed turnover may actually be privately inefficient and unproductive.

3. Restructuring requirements. Given the extent of catching up ahead of them, one would actually expect developing economies to have significantly higher investment and restructuring requirements. In fact, the extraordinary turnover rates experienced by Taiwanese firms may be a case in point. In their study of Taiwanese manufacturing industries, Aw, Chen and Roberts 1997 report that firms that entered over the previous five years account for between one-third and one-half of 1991 industry output (table 1). They report that the equivalent figures for manufacturing plants is 18 to 21 percent in Colombia; 15 to 16 percent in Chile; and 14 to 19 percent in the US (fn. 3, p. 7). Large turnover rates in Taiwan are an indication that developing countries have the potential to attain much higher restructuring rates absent major impediments.

Another useful natural experiment can be found in Eastern European transition. Haltiwanger and Vodopivec 1997 studied the case of Estonia, which was one of the most radical reformers. Estonia implemented major reforms in 1992. As reported in table 1, average annual job creation and destruction rates in Estonia over the period 1992-94 were 9.7 and 12.9 percent, respectively. Those figures are within the range observed in OECD economies. What is striking is that they coincided with a period of momentous reforms. For example, between 1989 and 1995, the share of private enterprises in total employment rose from 2 to 35 percent; and the share of establishments with more than 100 employees fell from 75 to 46 percent. In this context, observed job flows in Estonia were disappointingly low, which is not surprising given the major institutional deficiencies faced by transition economies.

\footnotetext{
${ }^{14}$ See Davis and Haltiwanger 1998, table 3.2, fn. b.
} 
4. Productivity. So far, our discussion was limited to the volume of the churn. Our theoretical discussion also pointed to other factors - privately inefficient separations and the scrambling in the productivity ranking of entering and exiting units - that reduce the quality of those flows. In principle, sclerosis is consistent with large flows if the latter are relatively unproductive. The quality of the churn can be measured by an accounting exercise of the type discussed in the previous section, which accounts for the aggregate productivity improvements associated with job flows. In our discussion of the results for Colombia and Taiwan, we pointed out that methodological issues do not allow direct comparison with results for the US. As importantly, it should be pointed out that those studies do not account for the scrapping and re-investment costs of restructuring. When a firm exits and is replaced by a higher-productivity entrant, one should account for the cost of scrapping investments in the former and reinvesting in the latter. This is particularly important in comparisons between high and low-income economies, when employment in the latter is biased toward light industries and other modes of production with low reinvestment costs.

It seems safe to conclude that cross-country comparisons based on raw job flow data are unlikely to provide conclusive evidence on the efficiency of restructuring. A more structural empirical approach is needed that addresses the type of issues discussed above. From this point of view, the corresponding empirical literature is still in its infancy.

\section{Crises, Recovery, and Productivity}

Recurrent crises in developing economies have large welfare consequences. Some of these consequences are immediately apparent, while others manifest their damage over time and thus are often under-appreciated. A potentially major impact of the latter type is the disruptive effect that crises can have on the restructuring process. In this section we explore this connection. After clarifying a widespread misconception concerning the 
relation between liquidations and restructuring, we report evidence that leads us to conjecture that crises slow down the restructuring process. If this is so, and given our presumption of sclerosis in the production structure, crises are even more costly than their contemporaneous impact on unemployment and other aggregate indicators may suggest.

At the origin of the above-mentioned misconception is a stark fact. Sharp liquidations constitute the most noted impact of contractions on restructuring. Figure 3 illustrates this point for the case of Chile's debt crisis in the early eighties. The job destruction rate exceeded 22 percent of manufacturing employment in 1981-82. Sharp employment liquidations during recessions are also documented for other countries. ${ }^{15}$ What is fallacious is the unwarranted inference that the concentration of liquidations during crises implies that crises accelerate the restructuring process. This view was highly influential among pre-Keynesian "liquidationists" - such as Hayek, Pigou, Robbins, Schumpeter who saw liquidations in a positive light as the main function of recessions (see De Long 1990). Although few economists today would take such an extreme position, many see in increased factor reallocation a silver lining of recessions. Observed liquidations are seen as a prelude to much-needed restructuring. Under the presumption of technological sclerosis due to poor institutions, increased restructuring can be beneficial. A variety of liquidationist arguments were advanced, for example, during the Asian crisis in connections with the reorganization of Korean chaebols.

Although there seems to be some truth to the notion that recessions facilitate reorganization at the level of politics and institutions, the relation between increased restructuring and increased liquidations is much less obvious insofar as we are concerned directly with adjustments in the productive structure. The fact is that lost jobs during recessions typically feed into formal unemployment or under-employment in the informal sector, not directly into increased creation - a phenomenon we interpreted in the previous section as a case of "unbalanced restructuring." The question is whether, ultimately,

15 See Davis, Haltiwanger and Schuh 1996 for evidence from US manufacturing. Where analyses have been conducted, they have shown that a large fraction of destruction during contractions is permanent (see Davis and Haltiwanger 1992). 
increased liquidations lead to increased restructuring. In order to assess this question, one needs to examine the cumulative impact of a recessionary shock on creation and destruction. In other words one needs to examine not only the effect of the crisis at impact, but also how the recovery materializes. Figure 4 illustrates this issue by showing three scenarios that are consistent with a given unemployment recession that starts with a spike in liquidations (bottom panel). The three scenarios correspond to cases where the recession results cumulatively in increased, unchanged, or decreased restructuring (panels (a), (b) and (c), respectively).

We examined this question empirically in Caballero and Hammour 1999 using data from the US manufacturing sector. Figure 5 presents the gross job creation and destruction time series constructed by Davis and Haltiwanger 1992 for US manufacturing. Most notable in those series are the sharp peaks in destruction at the onset of each recession, while the fall in creation is much more muted. Although this asymmetry between creation and destruction may not be as strong in other sectors, or when the economy is subject to shocks of a different nature, this evidence confirmed the long-held view that liquidations are highly concentrated in recessions.

Is the evidence in figure 5 supportive of increased restructuring following recessions? In order to examine the cumulative impact of a recessionary shock on creation and destruction, we ran a simple one-factor regression and calculated the impulse-response functions reported in figure $6 .{ }^{16}$ The bottom panel reports the cumulative impact of a recessionary shock on creation and destruction. Surprisingly, recessions seem to reduce the amount of restructuring in the economy. This result of "chill" following recessions is significant and robust in several dimensions, including the introduction of a second, reallocation shock. Given the limitations of the data, our conclusion can only be tentative.

\footnotetext{
${ }^{16}$ The regression underlying figure 6 uses manufacturing employment $\left(N_{t}\right)$, the flow of gross job creation $\left(H_{t}\right)$, and the flow of gross destruction $\left(D_{t}\right)$ in deviation from their mean. The data are quarterly for the period 1972:1-1993:4. We assume that employment fluctuations are driven by a single aggregate shock. Given the identity $\Delta N_{t}=H_{t}-D_{t}$, a linear time-series model for the response of job flows to aggregate shocks can generally be written either in terms of creation: $H_{t}=\theta^{h}(L) N_{t}+\varepsilon_{t}^{h}$; or in terms of destruction: $D_{t}$ $=\theta^{l}(L) N_{t}+\varepsilon_{t}^{d}$, where $\theta^{h}(L)$ and $\theta^{d}(L)$ are polynomials in the lag operator $L$. Figure 6 portrays the estimated impulse-response functions for a 2 -standard-deviation recessionary shock.
} 
But, if there is any evidence, it does not support prevailing views that recessions are the occasion for increased restructuring.

Why would recessions freeze the restructuring process? Based on the model we develop in Caballero and Hammour 1999, our interpretation is that the main underlying factors are financial constraints - again, a case of institutional failure. While liquidations and the open failure of bankrupt firms make the news, recessions also squeeze the liquidity and financial resources needed to create new, more advanced production units. As the latter takes place, the competitive pressure from new production units slows down and lowproductivity incumbents can survive more easily. The scarcity of financial resources during the recovery limits the socially useful transfer of resources from low to high productivity units. ${ }^{17}$

While we do not have access to the data required to reproduce the above study for a developing economy, it is plausible that the same phenomenon also characterizes crises in developing economies. ${ }^{18}$ If there is any difference, the liquidity contractions in those economies are more marked, and their depressing effect on creation during the recovery is likely to be even stronger. Figure 7, for example, illustrates the severe credit crunch in Mexico and Argentina that followed the "tequila" crisis of the mid-90s. The two lines in each panel depict the path of private deposits and loans. It is clear from this episode that

\footnotetext{
${ }^{17}$ Fluctuations in the pace of restructuring can be approached from a very different angle, by moving from job reallocation to the restructuring of corporate assets. Looking at merger and acquisition ("M\&A") activity over time, and at its institutional underpinnings, we reach a conclusion that also amounts to a rejection of the liquidationist perspective (see Caballero and Hammour 2000). Essentially, liquidationism in this context would consider fire sales during sharp liquidity contractions as the occasion for intense restructuring of corporate assets. The evidence points, on the contrary, to briskly expansionary periods characterized by high stock-market valuations and abundant liquidity as the occasion for intense M\&A activity. Again, financial factors and their institutional underpinnings seem to be at the core of this restructuring phenomenon.

${ }^{18}$ It would probably be unwise to look for direct evidence of depressed reallocation along the lines we did for the U.S. The reason is that crises in developing economies often involve large changes in relative prices (e.g., the large real devaluation during Mexico's tequila crisis), which naturally induce reallocation. The right metric is then one that controls for this purely neoclassical mechanism
} 
loans to the private sector not only recovered very gradually after the crisis, but also did so slower than deposits. ${ }^{19}$

In sum, even though direct evidence is lacking, it is likely that crises constitute another major obstacle to a well-functioning restructuring process, and that this disruption is closely associated with problems in financial markets. The result is a productivity-based social cost of economic crises that is incurred in addition to the traditional cost based on under-employment and the under-utilization of other resources. The cost of crises in terms of restructuring is twofold. First, crises are likely to result in a significant amount of privately inefficient liquidations, leading to large costs of job loss and liquidations of organizational capital. Second, crises are likely to result in a freezing of the restructuring process and years of productivity stagnation.

\section{Conclusion}

A core mechanism of economic growth in modern market economies is the massive ongoing restructuring and factor reallocation by which new technologies replace the old. This process of Schumpeterian creative destruction permeates major aspects of macroeconomic performance - not only long-run growth, but also economic fluctuations and the functioning of factor markets. Unfortunately, the process of creative destruction is also fragile, as it is exposed to political short-sightedness, inadequate contractual environments, and financial underdevelopment.

In this paper we have reviewed both theoretical arguments and empirical evidence supporting this creative-destruction view of macroeconomic performance and its problems. While the evidence we presented is mostly from developed economies, it is not a great leap to conjecture that it also applies in many of its dimensions to developing economies. In fact, the latter typically suffer from more severe deficiencies in their contractual environment, and their financial systems often suffer severe damage during

\footnotetext{
${ }^{19}$ The slow recovery of loans in Argentina was caused by government's crowding out as it borrowed to pay back for its "monetary" intervention and, most importantly to our argument, by the sharp consolidation process experienced by the banking sector following the crisis.
} 
crises. These are the two most significant ingredients behind sclerosis and behind inefficient restructuring following contractions.

There is no doubt that there is a significant need for new and more structural empirical evidence on the workings of the creative-destruction process and its perils in developing economies. We hope that this paper has pointed to some of the most promising issues in this worthy agenda. 


\section{References}

Aw, Bee-Yan, Xiaomin Chen and Mark Roberts (1997): "Firm-Level Evidence on Productivity Differentials, Turnover, and Exports in Taiwanese Manufacturing," NBER Working Paper no. 6235.

Baily, Martin, Charles Hulten and David Campbell (1992): "Productivity Dynamics in Manufacturing Plants," Brookings Papers on Economic Activity, Microeconomics, 187-267.

Banerjee, Abhijit V., and Andrew Newman (1998): "Information, the Dual Economy, and Development," Review of Economic Studies, 65, 631-653.

Bartelsman, Eric J., and Phoebus J. Dhrymes (1994): "Productivity Dynamics: U.S. Manufacturing Plants, 1972-1986," Discussion Paper 94-1, Finance and Economics Discussion Series, Federal Reserve Board.

Bertola, Giuseppe, and Richard Rogerson (1997): "Institutions and Labor Reallocation," European Economic review, 41, 1147-1171.

Caballero, Ricardo J. and Mohamad L. Hammour (1996a): "On the Ills of Adjustment," Journal of Development Economics, 51, 161-192.

- (1996b): "On the Timing and Efficiency of Creative Destruction," Quarterly Journal of Economics, 111(3), 805-852.

— (1998a): "The Macroeconomics of Specificity," Journal of Political Economy, 106(4), 724-767.

— (1998b): "Jobless Growth: Appropriability, Factor Substitution, and Unemployment," Carnegie-Rochester Conference Series on Public Policy, 48, 51-94.

- (1999): "The Cost of Recessions Revisited: A Reverse-Liquidationist View," NBER Working Paper No. 7355, September.

- (2000): “Technological Revolutions and Merger Waves," work in progress. 
Contini, Bruno, Lia Pacelli and others (1995): A Study on Job Creation and Destruction in Europe, A Study for the Commission of the European Communities.

Cox-Edwards, Alejandra (1993): Labor Market Legislatin in Latin America and the Caribbean, Latin American and the Caribbean Technical Department. Region Studies Program, report No. 31, Washington, DC: The World Bank.

Davis, Steven J., and John Haltiwanger (1992): "Gross Job Creation, Gross Job Destruction and Employment Reallocation," Quarterly Journal of Economics, 107, 819-864.

— (1998): "Gross Job Flows," in Orley Ahenfelter and David Card, eds., Handbook of Labor Economics, forthcoming.

Davis, Steven J., Haltiwanger, John, and Scott Schuh (1996): Job Creation and Destruction. Cambridge: MIT Press.

De Long, J. Bradford (1990): “ ‘Liquidation’ Cycles: Old-Fashioned Real Business Cycle Theory and the Great Depression," NBER Working Paper no. 3546.

Fernandez, Raquel, and Dani Rodrick (1991): "Resistance to Reform: Status Quo Bias in the Presence of Individual-Specific Uncertainty,” American Economic Review, 81(5), 1146-1155.

Greenspan, A. (1999): "Maintaining Economic Vitality," Millennium Lecture Series sponsored by the Gerald R. Ford Foundation and Grand Valley State University, September 8.

Grewenwood, Jeremy, Zvi Herkowitz and Per Krusell (1997): "Long-Run Implications of Investment-Specific Technological Change," American Economic Review, 87(3), 342-362.

Hart, Oliver, and John Moore (1994): "A Theory of Debt Based on the Inalienability of Human Capital," Quarterly Journal of Economics, 109, 841-879.

Haltiwanger, John, and Milan Vodopivec (1997): "Gross Worker and Job Flows in a Transition Economy: an Analysis of Estonia," typescript. 
Hulten, Charles R. (1992): "Growth Accounting When Technical Change is Embodied in Capital," American Economic Review, 82, 964-980.

Jovanovic, Boyan (1982): "Selection and the Evolution of Industry," Econometrica, 50, 649-70.

Klein, Benjamin, Robert G. Crawford, and Armen A. Alchian (1978): "Vertical Integration, Appropriable Rents, and the Competitive Contracting Process," Journal of Law and Economics, 21(2), 297-326.

Levinsohn, James (1999): "Employment Responses to International Liberalization in Chile," Journal of International Economics 47, pp. 321-344.

Lin, Justin Yifu, and Jeffrey B. Nugent (1995): "Institutions and Economic Development," in J. Behrman and T.N. Srinivasan, eds., Handbook of Economic Development, vol. 3A, Amsterdam: North-Holland.

Liu, Lili, and James R. Tybout (1996): "Productivity Growth in Chile and Colombia: The Role of Entry, Exit and Learning," in in Mark. J. Roberts and James R. Tybout, eds., Industrial Evolution in Developing Countries: Micro Patterns of Turnover, Productivity, and Market Structure, Oxford: Oxford University Press.

Melitz, Marc J. (1999): "The Impact of Trade on Intra-Industry Reallocations and Aggregate Industry Productivity," typescript, University of Michigan.

Mokyr, Joel (1992): “Technological Inertia in Economic History," Journal of Economic History, 52(2), 325-338.

Olley, Steven, and Ariel Pakes (1996): "The Dynamics of Productivity in the Telecommunications Equipment Industry," Econometrica, 64, 1263-1297.

Ramey, Valerie A., and Matthew D. Shapiro (1998): "Displaced Capital," NBER Working Paper 6775.

Roberts, Mark J. (1996): "Employment Flows and Producer Turnover in Three Developing Countries," in Mark. J. Roberts and James R. Tybout, eds., Industrial Evolution in Developing Countries: Micro Patterns of Turnover, Productivity, and Market Structure, Oxford: Oxford University Press. 
Roberts, Mark J., and James R. Tybout, eds. (1996): Industrial Evolution in Developing Countries: Micro Patterns of Turnover, Productivity, and Market Structure, Oxford: Oxford University Press.

Schumpeter, Joseph A. (1942): Capitalism, Socialism, and Democracy. New York: Harper and Brothers.

Thomis, Malcolm (1972): The Luddites, New York.

Tybout, James (1998): "Manufacturing Firms in Developing Countries: How Well Do they Do, and Why?" Journal of Economic Literature, Vol. 38, March 2000, pp. 1144. 
Table 1: International Comparison of Average Annual Gross Job Flow Rates (\% of Employment)

\begin{tabular}{lcllcc}
\hline Country & Period & Coverage & $\begin{array}{l}\text { Employer } \\
\text { Unit }\end{array}$ & Job Creation & $\begin{array}{l}\text { Job } \\
\text { Destruction }\end{array}$ \\
\hline High Income & & & & & \\
Canada & $1974-92$ & Manufacturing & Plant & 10.90 & 11.10 \\
Canada & $1983-91$ & All Employees & Firm & 14.50 & 11.90 \\
Denmark & $1981-91$ & Manufacturing & Plant & 12.00 & 11.50 \\
Denmark & $1983-89$ & Private Sector & Plant & 16.00 & 13.80 \\
Finland & $1986-91$ & All Employees & Plant & 10.40 & 12.00 \\
France & $1985-91$ & Manufacturing & Firm & 10.20 & 11.00 \\
France & $1984-92$ & Private Sector & Plant & 13.90 & 13.20 \\
Germany & $1983-90$ & All Employees & Plant & 9.00 & 7.50 \\
Italy & $1984-93$ & Private Sector & Firm & 11.90 & 11.10 \\
Netherlands & $1979-93$ & Manufacturing & Firm & 7.30 & 8.30 \\
New Zealand & $1987-92$ & Private Sector & Plant & 15.70 & 19.80 \\
Norway & $1976-86$ & Manufacturing & Plant & 7.10 & 8.40 \\
Sweden & $1985-92$ & All Employees & Plant & 14.50 & 14.60 \\
USA & $1973-93$ & Manufacturing & Plant & 8.80 & 10.20 \\
USA (a) & $1979-83$ & Manufacturing & Plant & 10.20 & 11.50 \\
USA (a) & $1979-83$ & Private Sector & Plant & 11.40 & 9.90 \\
United Kingdom & $1985-91$ & All Employees & Firm & 8.70 & 6.60 \\
& & & & & \\
Middle and Low Income & & & & & \\
Colombia & $1977-91$ & Manufacturing & Plant & 12.50 & 12.20 \\
Chile & $1979-86$ & Manufacturing & Plant & 13.00 & 13.90 \\
Estonia & $1992-94$ & All Employees & Firm & 9.70 & 12.90 \\
Morocco & $1984-89$ & Manufacturing & Firm & 18.60 & 12.10 \\
& & & & & \\
\hline Source: Davis and Hafiwanger (1998), table 3.2 & & \\
\hline
\end{tabular}

Source: Davis and Haltiwanger (1998), table 3.2

(a) Selected states. Based on data for employers covered by Unemployment Insurance. 
Table 2: Average Persistence Rates for Annual Job Flows (\%)

\begin{tabular}{lccccc}
\hline Country & Period & Job Creation & Job Destruction & Job Creation & Job Destruction \\
\hline & & & & & \\
Denmark & $1980-91$ & 71.0 & 71.0 & 58.0 & 58.0 \\
France & $1985-90$ & 73.4 & 82.1 & 51.5 & 68.2 \\
Netherlands & $1979-93$ & 77.9 & 92.5 & 58.8 & 87.3 \\
Norway & $1977-86$ & 72.7 & 84.2 & 65.1 & 79.8 \\
USA & $1973-88$ & 70.2 & 82.3 & 54.4 & 73.6 \\
& & & & & \\
\hline
\end{tabular}

Source: Davis and Haltiwanger (1998), table 3.6

Table 3: Fraction of Excess Job Reallocation Accounted for by Employment Shifts Between Sectors

\begin{tabular}{|c|c|c|c|c|c|c|}
\hline Country & Period & Classification Scheme & $\begin{array}{l}\text { Employer } \\
\text { Unit }\end{array}$ & $\begin{array}{l}\text { Number } \\
\text { of Sectors }\end{array}$ & $\begin{array}{l}\text { Average } \\
\text { Workers per } \\
\text { Sector ('000) }\end{array}$ & $\begin{array}{l}\text { \% From Shifts } \\
\text { Between } \\
\text { Sectors }\end{array}$ \\
\hline
\end{tabular}

High Income

$\begin{array}{lcllccc}\text { Finland } & 1986-91 & \text { 2-digit ISIC } & \text { Plant } & 27 & 49 & 6 \\ \text { France } & 1985-91 & \text { Detailed Industry } & \text { Firm } & 600 & 37 & 17 \\ \text { Germany } & 1983-90 & \text { 2-digit ISIC } & \text { Plant } & 24 & 1,171 & 3 \\ \text { Italy } & 1986-91 & \text { 2-digit SIC Private Sector } & \text { Firm } & 28 & 322 & 2 \\ \text { Netherlands } & 1979-93 & \text { 2-digit SIC } & \text { Firm } & 18 & 10 & 20 \\ \text { New Zealand } & 1987-92 & \text { 2-digit ISIC } & \text { Plant } & 28 & 28 & 1 \\ \text { Norway } & 1976-86 & \text { 5-digit ISIC Manufacturing } & \text { Plant } & 142 & 2 & 6 \\ \text { Sweden } & 1985-91 & \text { 2-digit ISIC } & \text { Plant } & 28 & 112 & 3 \\ \text { USA } & 1972-88 & \text { 4-digit SIC Manufacturing } & \text { Plant } & 448 / 456 & 39 & 13\end{array}$

Middle and Low Income

$\begin{array}{lllllll}\text { Chile } & 1979-86 & \text { 4-digit Manufacturing } & \text { Plant } & 69 & 4 & 12 \\ \text { Colombia } & 1977-91 & \text { 4-digit Manufacturing } & \text { Plant } & 73 & 6 & 13 \\ \text { Morocco } & 1984-89 & \text { 4-digit Manufacturing } & \text { Plant } & 61 & 4 & 17\end{array}$

Source: Davis and Haltiwanger (1998), table 3.5 
$\underline{\text { AUTARKY }}$
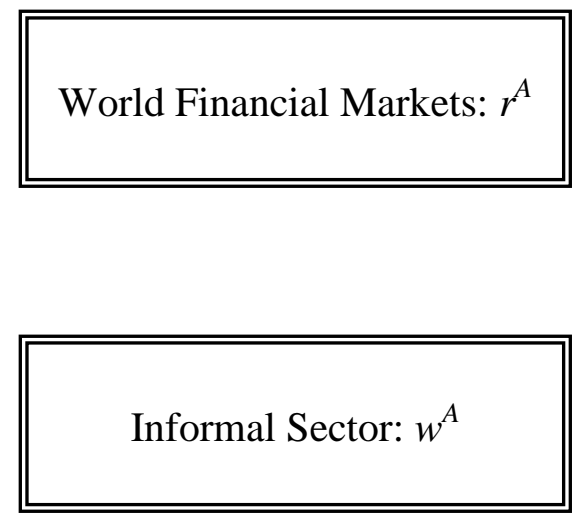

$\underline{\text { JOINT PRODUCTION }}$

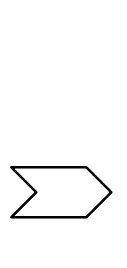

Outside Capital: $b=1-a$<smiles>C1=CCCC1</smiles>

Entrepreneur: $y_{i}$ Inside Capital: $a$<smiles>C1CCCC1</smiles>
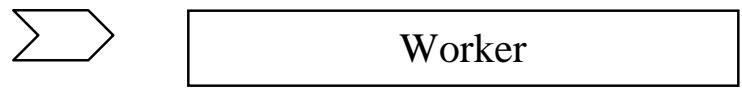

Production Unit

$\Rightarrow$ Direction of specificity

Figure 1: Autarky and Joint Production 


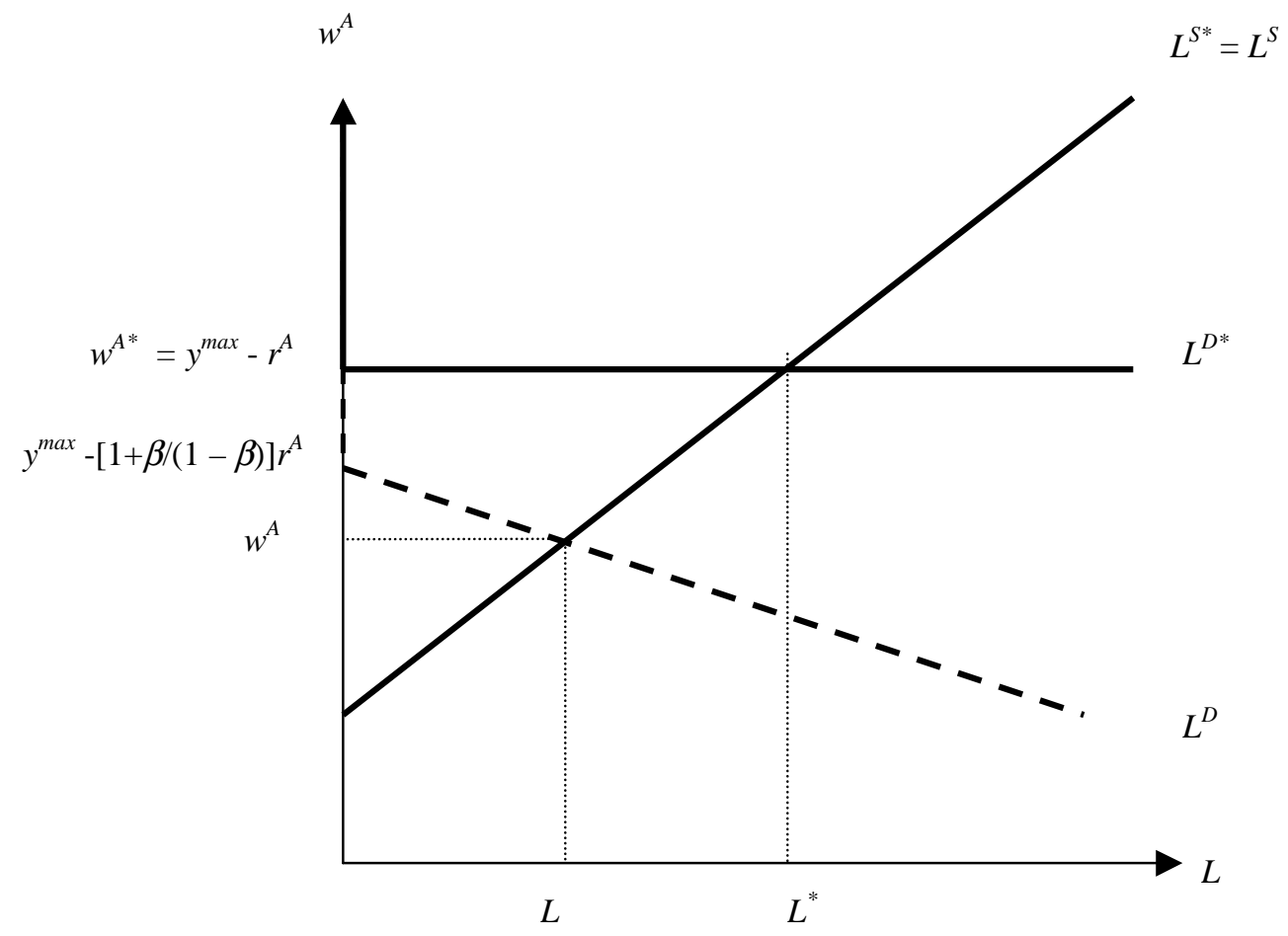

Figure 2: Efficient and Incomplete-Contracts Equilibria 


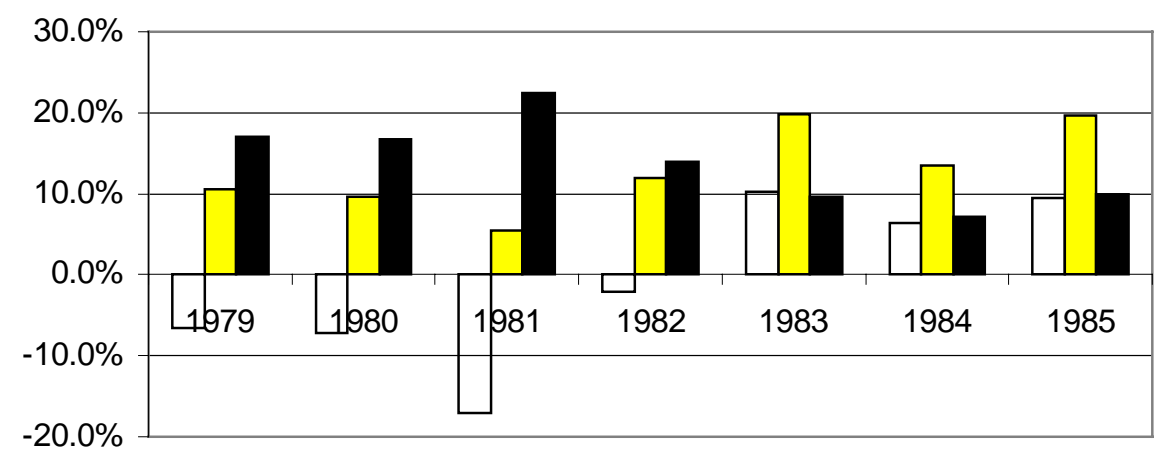

$\square$ Net Creation $\square$ Gross Creation $\square$ Gross Destruction

Source:Roberts 1996, table 2.2

Figure 3: Gross Manufacturing Job Flows in Chile (1979-86) 


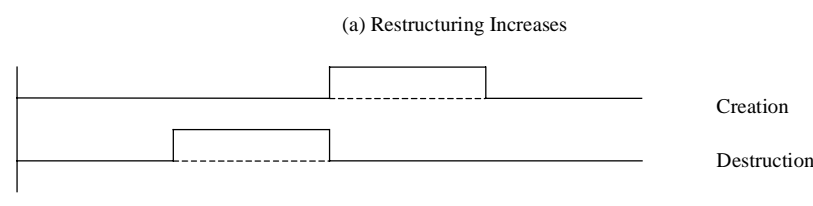

(b) Restructuring is Unchanged

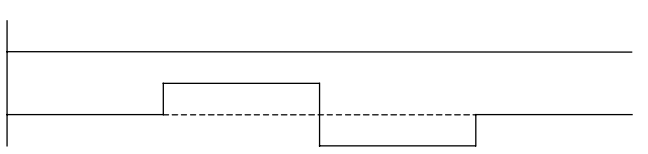

Creation

Destruction

(c) Restructuring Decreases

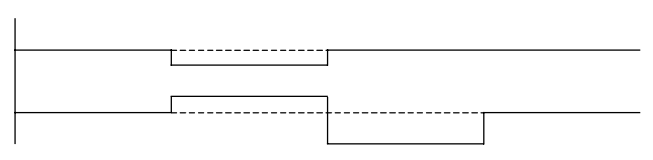

Creation

Destruction

(d) Unemployment Recession

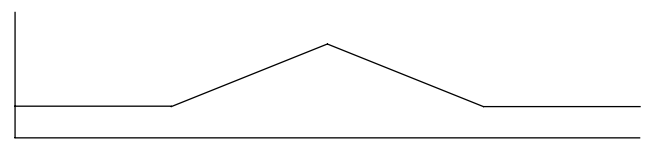

Unemployment

Time

Figure 4: Crises and Cumulative Restructuring 


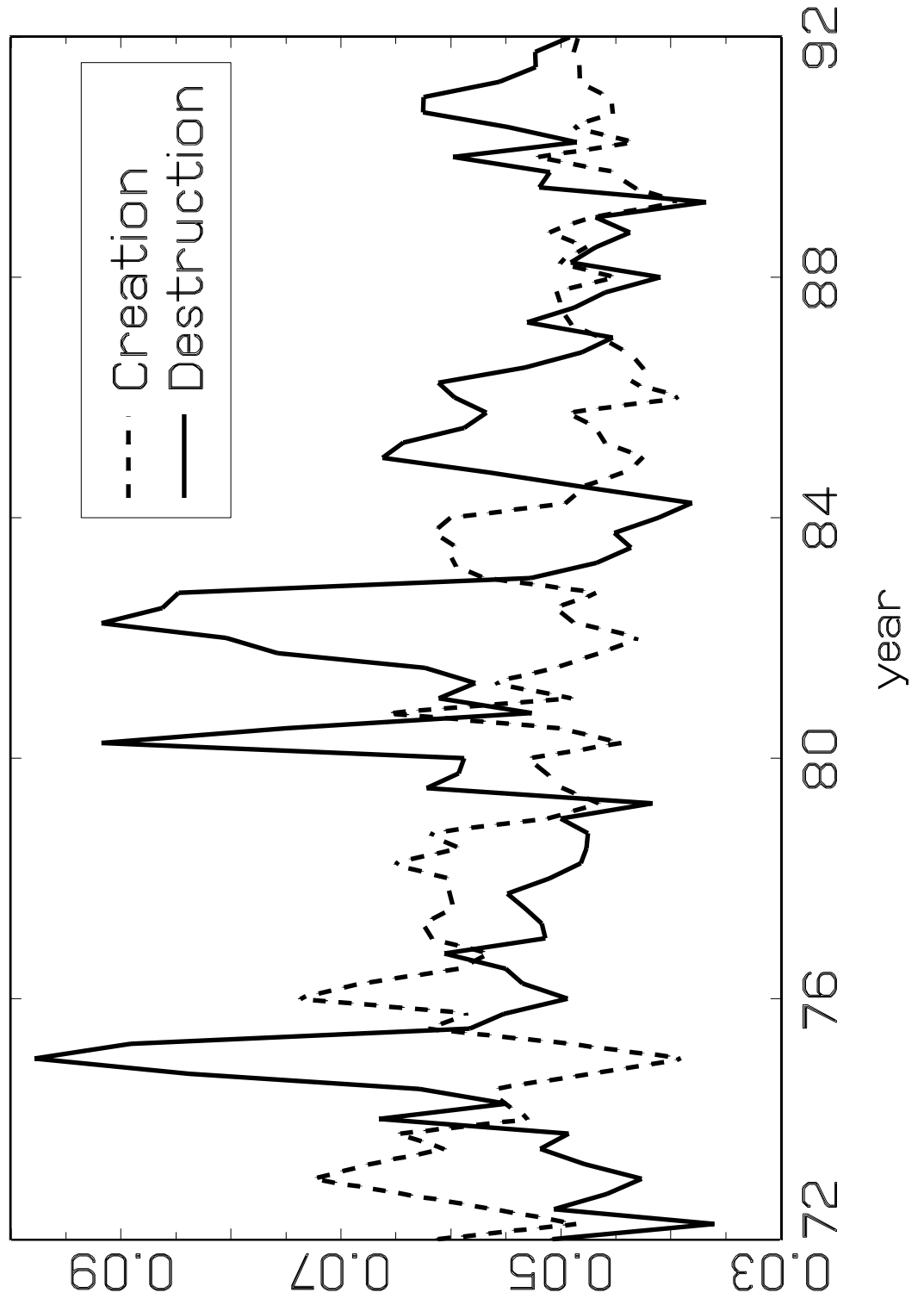

Figure 5: Gross Manufacturing Job Flows in the US (1972-92) 
(a) Restructuring Increases

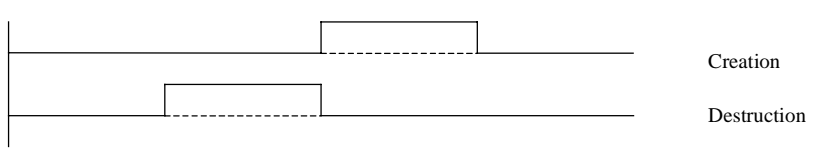

(b) Restructuring is Unchanged

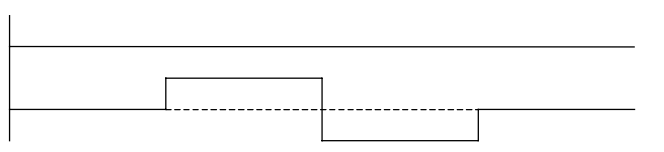

Creation

Destruction

(c) Restructuring Decreases

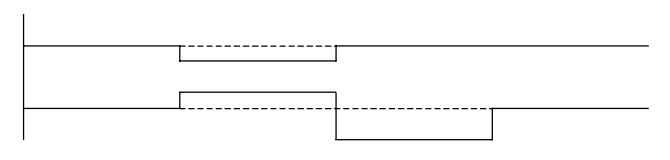

Creation

Destruction

(d) Unemployment Recession

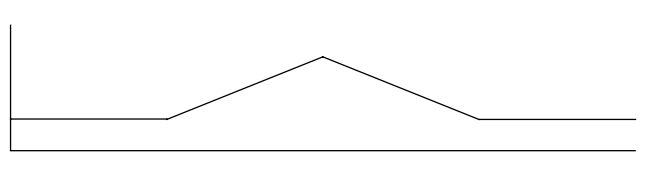

Unemployment

Time

Figure 6: A Case of Chill 


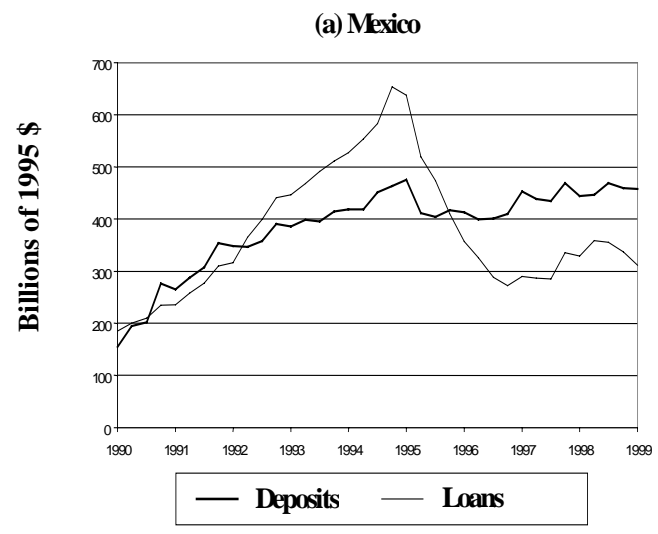

(b) Argentina

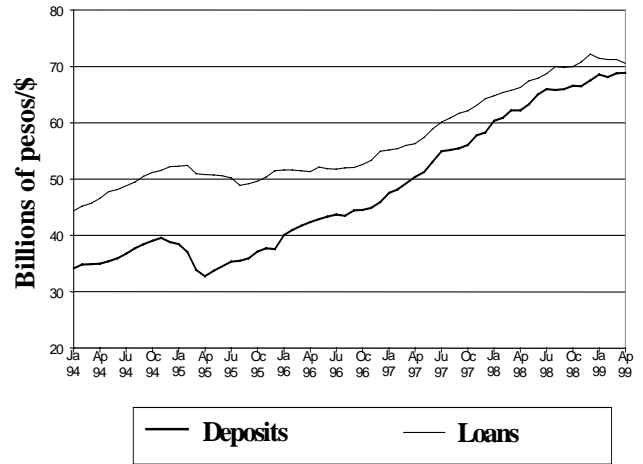

Figure 7: Credit Crunch in Argentina and Mexico 